\title{
THE MANAGEMENT OF TEACHING ENGLISH WRITING AT KINDERGARTEN
}

\author{
Sulistiyani $^{1}$, Norma Diana Fitri ${ }^{2}$ \\ ${ }^{1,2}$ STKIP Bina Insan Mandiri Surabaya \\ ${ }^{1}$ sulistiyani@stkipbim.ac.id, ${ }^{2}$ normadiana@stkipbim.ac.id
}

Received: December 05, 2020 Revised: December 7, 2020 Accepted: December 11, 2020

\begin{abstract}
School-Based teaching English writing at kindergarten activities will improve student achievement, for example students who were once quiet now are active in the learning process. With the ongoing writting narrative text to form the potential for student learning, includes cognitive, affective and psychomotor aspects, student intelligent can be developed optimally hence it is well formed. With a constructivism approach, the teacher carries out learning in study groups. Students at kindergarten are divided into groups with heterogeneous members. In this study, researchers The researcher uses descriptive qualitative because it is more interested in the quality of a particular activity and then it will be evaluated and also it was designed to explain or to describe a condition objectively. This implies that the level of teaching English writing at kindergarten shows a positive impact. The level of of teaching English writing at kindergarten will give more influence well to the performance of teachers
\end{abstract}

Keywords: Management, Teaching English Writing, Kindergarten

\section{Introduction}

\subsection{The Background of the Study}

English as International language has an important role in the world. Not only used in communication, but also in transferring information. Based on the school- 
based curriculum in school, in English subject the students have to understand and create some short functional texts such as narrative text.

English Writing skill is one of the skills taught in Indonesia. Writing is a part of learning process that has to be mastered by all students in Indonesia. It is supported by Harmer (1988) who states that writing is one of compulsory skills that determined in part of syllabus in teaching of English. Hence, it still holds an important place in examinations in high school level in Indonesia.

Writing is a process of transferring ideas into written form that is understandable. Writing is one of important skill that must be mastered by the learners, but the fact many students less to write narrative text. And the narrative text is one of important genre of the text has known by the students, so that's why the writer choose this genre because the students still confusing about how to identify the generic structure and the use of language features in narrative text. According to Rebecca (2003) a narrative text is a text, which relates a series of logically, and chronologically related events that are caused or experienced by factors. She, furthermore, states that a key to comprehending a narrative is a sense of plot, of theme, of characters, and of events, and of how they relate.

The English teacher is lack of media and uninterested materials in teaching writing. It makes the students feel bored and do not understand about the lesson. Some students think that English is difficult, especially in writing. Teacher just teach English based on English book. And teacher does not use the method. It is cause the students have not motivation study English especially at young learner.

To solve these problems are to change the teaching method and management. According to the concept of Total Quality Management (TQM) in education especially for young learner, confirmed by Sallis (2006: 73), TQM is a philosophy of continuous improvement, which can provide a set of practical tools to every educational institution in meeting the needs, desires, and expectations of the customers, now and in the future. The success of teaching can be viewed from two aspects, namely from the process and from the result.

The teacher can using fairy tale stories as a material to facilitate students more easier understanding about content, organazitation, vocabulary, grammar and mechanic of the narrative text genre. Fairy tales might be considered one of the 
possible supplementary teaching materials for English language learners. They teach moral and values highlighting the most universal norms and standards of language existence. In addition to that, fairy tales are a particular type of text which can be adapted to suit the child's age, whereas their composition of sentences and plot is simple and understandable. But, fairy tales cannot be classified as children's stories; they have special quality of being able to entertain reader of all ages. Originally fairy tales main audience were adults as likely as children stated by Kerven (2008).

\section{Learning Community at young learner/kindergarten}

Community learning or group learning is learning activity by a number of students who have been divided into small groups to achieve certain goals. Many Indonesian teachers do not realize their responsible that being a teacher is not only dealing with their attendance in the class but also dealing with their strategy to facilitate the learner needs, the tools they used and the result that students achievement, the media, the good material, and many more necessary aspect especially at young learners. Therefore, the teachers as the facilitators should be responsible to find the solution of the problem. They should change and develop their teaching strategy in writing, so the satisfaction of teaching and learning activities is able to be obtained and student's motivation can be increased especially at young learner.

Based on the background of the study above, the writer formulates the research question as follows: Can fairy tale improve the writing skill of the kindergarten?

The purpose of the study is follow:

To describe whether fairy tales can improve students' narrative writing skill.

This study has two significances. Theoretically, this study is significant because it gives contribution to EFL teaching-learning issues that pose on classroom interaction. Practically, this study will provide information about the improvement of students' writing skill using fairy tales stories especially at young learner.

\section{Related Literature}




\section{II.I Writing skill}

Writing skill is one of the skills that should be learned by the students. Writing is not only the activity of arranging words into well organized of writing but also actually encourages thinking and learning when students view writing as a continuous process. It is supported by Wallace (2004: 15) states that writing is the final product after students learn several stages of writing separately before. There are three aspects of writing skill that have to be outlined in this discussion. The first aspect is about micro and macro skill of writing, the second is mechanical and components of writing and the last is cohesion and coherence of writing.

1. Mechanical and components of writing

Mechanical components are the second important matter of writing. Strakey (2004) addressed writing mechanics in terms of grammar, spelling, punctuation, and capitalization. Grammar is a key element not only in writing, but in language as a system of communication in general. Having a good knowledge of the parts speech, the structure of the language and its rhetorical devices, and knowing how to write comprehensively are what writing requires.

Capitalization and punctuation marks are integral parts of written English. Similarly, spelling is an important aspect in writing because it is an aspect that teachers focus on when evaluating students' work. Correct spelling gives one's work credibility. Not only will the reader know that one is educated, but also that he is careful about his work.

\section{Cohesion and coherence of writing}

The two aspects have an important role in writing process and cannot be separated each other. According to Richard (2007: 21) state that sentences also need to be cohesive and the whole text needs to be coherent. Thus, students also have to be supplied with the knowledge of cohesiveness and coherence. Cohesion can be defined as linking relationship of a number of linguistics elements that can be seen in a structure of the text surface. 
On the other hand, coherence is defined in slightly different way that is whether the writing works can easily be read and understood. Murray and Hughes (2008: 45) notice that a good writer is the one who sticks his ideas together as links in a chain, each link connecting the one before it with the one after. If any links are missing, the connections become unclear and the argument structure breaks down.

In summary, mechanical components of writing, and cohesion and coherence of writing are important aspects of writing. All of them have contributions in producing a good writing. Therefore, the teacher should consider teaching them to the students in order to make their students' writing works more accessible especially at young learner.

\section{II.2. Teaching Writing}

The teaching of writing skill has some objectives and indicators. It is stated in BSNP (2006) that teaching and learning of writing skill is targeted to achieve a functional level. On the functional level, students are able to communicate adequately both in spoken and written form to complete daily activities. Objectives of the teaching of writing skill can be achieved though some approaches. According to Harmer (2001: 25) there are two approaches in teaching writing. They are focusing on the product of writing process and focusing on the writing itself. He stated that focusing on the writing process leads those who advocate a process approach in writing.

In teaching writing especially the teacher should guide students in order that the students have good skills in writing many kinds of texts that should be taught based on the students's grade. Therefore, the students are expected to have good knowledge on how to make a good paragraph based on the purpose with good arrangement of the genre of texts that should be mastered by the students. It has been mentioned earlier that teaching writing is not an easy job especially at young learner.

Richards and Renandya (2002: 303) argue that with so many conflicting theories around and so many implementation factors to consider, planning and teaching a course in writing can be a daunting task. It is because the skills 
involved in writing are highly complex. Therefore, as a productive skill, writing must be taught in a comprehensive way.

Based on the statements above, In teaching writing, there are many methods used to teaching writing. One of them is genre approach. In this study, the teacher use genre approach to improve students writing skill especially at young learners.

\section{3. Genre Approach}

Genre-based writing teaching is concern with what learners do when they write. Genre argues that the researcher do not just write, the researcher writes something to achieve some purposes, as writing is a way of getting things done. This concept of teaching especially at young learners guides language learners to the ways they can most effectively achieve their purposes by systematically relating language to context. According to Hylland (2004: 25) context is not just the background against which writing takes place; it is co-constructed by the writer and reader to anticipating each other's responses and needs. It is also as the co-constructing meaning through discourse.

\section{II.4. Narrative Text}

Narrative text is one of the genres taught for the tenth grade students at Senior High School. According to Anderson and Anderson (2003a) explain that a narrative is a text that tells a story and, in doing so, entertains the audience. It has character, setting, and action. The characters, the setting, and the problem of the narrative are usually introduced in the beginning. The problem reaches its high point in the middle. The ending resolves the problem especially at young learners.

\section{5. Fairy tale}

A fairy tale is a story which involves folkloric features such as fairies, goblins, princes and princesses. The fairy tales is a sub-class of the folk tale. Originally fairy tales main audience were adults as likely as children stated by Kerven (2008). Fairy tales as a part of the children's literature could be a valuable source for teaching English as a foreign language. Fairy tales might be considered one of the possible supplementary teaching materials for English language learners. It is not only the atmosphere of 
mystery, thrill and wonder which makes fairy tales so unique and valuable but they can bring the whole magic world to a young reader and learner especially at young learners. There are two aspects of writing skill that have to be outlined in this discussion such as mechanical and components of writing and cohesion and coherence of writing.

\section{a. Folktales}

According to Bascon as quoted by Norton (1983: 97) are prose narratives which are regarded as fiction. They are not considered as dogma or history they may, or may not have happened and they are not taken seriously. Norton adds, "Because the tales are set in any time of any place, they are considered almost timeless and placeless." They usually tell the adventurous of animal or human characters. Folktales have no identified original author. They have been handed down from generation to generation by words of mouth.

\section{5. Teaching EFL}

Based on Depdiknas (2006) the goal of English teaching especially at young learners is to provide the students with knowledge and skills to make them able to communicate in English either in spoken or written language at the informational level. It means that students should be able to use the language to access and share information as a part of their learning either in spoken or written form. In order to achieve the goal, the English teacher should consider some relevant matters especially at young learner. Teaching English, especially teaching writing has the goal. Basically, teacher teaches writing to his or her students because he or she wants his or her students to be able to learn English easily and especially be able to write well.

In teaching writing, teacher has some roles during teaching and learning process.

\section{6. Teaching Writing Narrative Text Using Fairy tale}

\section{Definition of Teaching Writing Narrative Text}

Teaching English, especially teaching writing has the goal. Basically, teacher teaches writing to his or her students because he or she wants his or her students to be able to learn English easily and especially be able to write well.

Writing a narrative is much different from telling a story because you must organize more rigidly and select more strictly. We have to think a conflict 
before we begin to write. All narratives are based on conflict on a clash between ideas, people, or things. It need not be violent. Sometimes conflict is just a matter of a difference between ideal and the real especially at young learners.

Besides we have to follow that structure, a good story must have interesting content. It should tell about an event our audience would find engaging. We might even think of our narrative as a movie in which the audience see people in action and hear them speak. Therefore, writing a narrative is more difficult than telling the story orally especially at young learners. Teaching narrative writing is not different from teaching writing of other genres that can follow modern theories of learning in giving considerable recognition to the importance of collaboration, or peer interaction, and scaffolding, or teacher supported learning especially at young learners.

\section{Methodology}

\section{III.1. Research Design}

This study is attempting to observe students' ability to write well by using fairy tale stories. The researcher has purpose to find information on how the students' expert especially at young learner to expand their writing by using fairy tale stories and it should be guided in descriptive qualitative. The researcher uses descriptive qualitative because it is more interested in the quality of a particular activity and then it will be evaluated and also it was designed to explain or to describe a condition objectively.

Since the aim of the study to find out whether fairy tale improve or not, the researcher selects a CAR because there are many possible reasons for conducting a classroom action research as follow: The researcher wants to know more about students and the difficulties in learning process. The researcher wants to gauge the interest generated by certain topics, or judge the effectiveness of certain activities types.

This is categorize as action research since it attempts to improve the real condition of the writing teaching and learning process by involving participants in the setting where the research was done. Collecting the obstacles and weaknesses of the writing teaching and learning process, identifying the collected problems, planning, carrying out the actions, evaluating and reflecting the actions implemented were done collaboratively with the members involved. Carrand Kemmis (1986) in Burns 
(1999:30) argue that action research is a form of self-reflective enquiry done by participants in social situations (e.g. teachers, students, school principals in educational situation) for improving their own social and educational practices, and the situations in which these practices are carried out.

\section{Planning}

The researcher and the English teacher made a planning to do the feasible actions that would be implemented. The planning covered the identified problem based on the result of test and observation.

\section{Act \& Observe}

The action is conduct by the researcher whereas the English teacher observed the process. The purpose of this step is to solve the problem which is students' low writing skill using fairy tale. The actions would be implemented with some modification after looking at the results in the first cycle. Any recorded data guided the researcher to do the next step.

\section{Reflecting}

The reflection was conducted by giving test to students for their responses to the actions. The reflection was useful to show the effectiveness of the action conducted in the teaching and learning processes. The results of the identification are determine as successful or unsuccessful ones. The successful actions are use and reapply in the next cycle, but those which are unsuccessful will be change or improve into the suitable one.

The data of study are categorized into two : qualitative data and quantitative data. The quantitative data are those represented by the students' score writing test, while the qualitative data are in the observation.

\section{b. Hypothesis}

The hypothesis will be stated as follows:

Fairy tale can improve narrative writing skill of the kindergarten.

\section{c. Success Indicator}

The students' achievement and failure in doing the activities planned assessed by referring the criterion issued by Minimum Passing grade Criteria. A material could be 
said that it is successfully taught if students have minimal score 75 . It means that $75 \%$ of the material is mastered by students especially at young learners.

\section{d. Data Collection}

This section discusses about the instruments used during the action research. They are questionnaire and test.

\subsubsection{Observation}

The observation sheet is conducted during the teaching and learning activities in the class. The English teacher observes the researchr's performance during classroom action research, class situation while writing activity, and the students' participants toward the learning process. The information that obtained from this observation sheet is used as a basis to determine the planning for the following cycle.

\subsubsection{Test}

A test is a method of measuring one's ability or knowledge in a given area. A test of writing may consist of the components such as its content, grammar, organization, vocabulary, and mechanics. According to Brown (1980: 25), there are five kinds of tests: proficiency, aptitude, diagnostic, placement, and achievement test. In this action research the researcher provide diagnostic test in first reflection and end cycle test in every cycle. The researcher intend to check the students' understanding in learning narrative. The researcher want to know whether the students could learn narrative better and they can improve their ability in writing from the analysis of the test result.

\subsection{Data Analysis}

The analysis qualitative data is used to measure data from observation, while the analysis quantitative data is used to measure data from test. In analysing the data related to the students' writing skill, the researcher used analytical scoring rubic adapted from Jacobs et al. (2002;116) In Weigle's book:

\section{Discussion}

Discussion of the results at research conducted through two kinds, namely the description of each variable and the results of correlation analysis between variables. Correlation analysis of each variable can be explained as follows that the range of educational grade scores between 1 to 3 and most are in the high score classification that is equal to $51 \%$. The range of work experience scores ranges from 50 to 72 and 
most of them are in the moderate score classification of $57 \%$. While the range of teaching English writing scores between 48 to 78 and most are classified moderate, that is equal to $64 \%$. analysis of the correlation between the variable level of education and work experience with the performance of English teacher at kindergarten. Significant influence between teaching English writing at kindergarten is so high in the education environment, especially at the young learners

\section{REFERENCES}

Akmala, Tatum Ariesya. 2011. The use of animated film to improve Students' ability In writing narrative text: A Classroom Action Research at the 10th Grade of Madrasah Aliyah Negeri Pemalang in the Academic Year of 2010/2011. (Online). (http://library.walisongo.ac.id/digilib/files/disk1/105/jtptiain-gdltatumaries-5202-1-tatumar-a.pdf accessed 21 ${ }^{\text {th }}$ May 2016).

Anderson, M. \& Anderson, K. 2003a. Text Types in English 2. Macmillan Education Australia PTY LTD.

Brown. 2001. Teaching by Principles: An Interactive Approach to Language Pedagogy. Second Edition. White Plains, NY: Pearson Education.

Burns, Anne. 1999. Collaborative Action Research for English Language Teachers. New York: Cambridge University Press.

Carnine, D. et.al. 1990. Summary of Internet Sites. Bos Informasi. (Online). (http://www.bosinformasi.web.id/2014/12/narrative-text-and-itsexplanation.html, accessed on $22^{\text {th }}$ March 2017).

Depdiknas. 2006. Kurikulum Tingkat Satuan Pendidikan (KTSP). Jakarta: Depdiknas.

Harmer, Jeremy. 2001; 31. How to Teach Writing, England: Pearson Education Limited.

Kerven, R. 2009. English Fairy Tales and Legends. National Trust. 
Kready, L. F. 1916. A Study of Fairy Tales. (Online) (http://dspace.ut.ee/bitstream/handle/10062/26014/Lepin.pdf accessed on 10th April 2017).

Kemmis, Stephen and Robin McTaggart (eds.), 1988. The action research planner. Victoria, Australia: Deakin University Press.

Literacy and Education Research Network And Directorate of Studies. 1990. A Genre Based Approach to Teaching Writing in years 3-6: Book 4: Writing Stories: A Teaching Unit Based on Narratives About Fairy Tales. NSW: Common Ground.

Norton, Donna E. 1983. Through the Eyes of a Child: An Introduction to Children's Literature. London: A Bell and Howell Company.

Nura, A. 2003. Problematik pengajaran keterampilan menulis lanjut: Upaya menumbuh kembangkan minat menulis di usia dini. (Online), Komposisi, Vol. 4 No 1, 69-80. Padang: FBSS UNP Press.

Randal, H. 2004. Literacy an Introduction. Edinburgh: Edinburgh University.

Rebecca, J. L. 2003. A Critical Handbook of Children's Literature. Massachuset: Pearson Education, Inc.

Richard, J. C. 2007. 30 Years of TEFL / TESL. Singapore: SEAMEO Regional Language

Richards, J. C and Willy A. Renandya. 2002;303. Methodolgy in Language Teaching: Ontology of Current Practice. New York: Cambridge Univ. Press.

Sudaryanto. Februari 2001. Peningkatan keterampilan menyusun wacana narasi melalui penerapan pendekatan ekletik. Cakrawala Pendidikan. Th XX, No $1,61-69$.

Sudijono, Anas. 2008. Pengantar Statistik Pendidikan. Jakarta: PT. Raja Grafindo Persada. 
Starkey. 2004; 39. Developing EFL Writing Skill through the Use of the Process Approach: A Case Study of Second Year Students at Mohammed Kheider University of Biskra. (Online). (http://dspace.univbiskra.dz:8080/jspui/bitstream/123456789/6016/1/Djidel\%20Souhila.pdf accessed on $9^{\text {th }}$ April 2017).

Swales, John M. 1990. Genre Analysis. Cambridge: Cambridge University Press.

Weigle, Sara Cushing. Assessing Writing. Cambridge: Cambridge University Press, 2002.

Wallace, Trudy. 2004. Educational Practices Series-14: Teaching Speaking, Listening, and Speaking. Geneva: International Bureau of Education - Publications Unit. 